\title{
Saccharopolyspora spinosporotrichia sp. nov., a novel actinomycete from soil
}

\author{
Zhi-Hong Zhou, ${ }^{1,2}$ Zhi-Heng Liu, ${ }^{1}$ Yu-Dong Qian, ${ }^{1}$ Seung Bum Kim² \\ and Michael Goodfellow ${ }^{2}$
}

Author for correspondence: Zhi-Heng Liu. Tel: +861062553628 . Fax: +861062560912.

1 Institute of Microbiology, Chinese Academy of Sciences, Beijing 100080 , People's Republic of China

2 Department of Microbiology, The Medical School, Framlington Place, Newcastle upon Tyne NE2 4HH, UK

\begin{abstract}
The generic position of an aerobic, Gram-positive, non-acid-alcohol-fast actinomycete was determined following isolation of the PCR-amplified 165 rRNA genes and alignment of the resultant sequence with corresponding sequences from representatives of the family Pseudonocardiaceae. The assignment of the organism to the genus Saccharopolyspora was strongly supported by chemotaxonomic and morphological data. The strain was distinguished from representatives of validly described Saccharopolyspora species by a number of phenotypic properties. It is proposed that the organism, strain AS4.198', be classified in the genus Saccharopolyspora as Saccharopolyspora spinosporotrichia sp. nov.
\end{abstract}

Keywords: Saccharopolyspora spinosporotrichia sp. nov., 16S rDNA sequences

\section{INTRODUCTION}

The genus Saccharopolyspora was proposed by Lacey \& Goodfellow (20) for actinomycetes isolated from spontaneously heated, sugar-cane bagasse. The genus currently encompasses aerobic, non-acid-fast organisms which form extensively branched substrate hyphae that fragment into rod-shaped, non-motile elements, and aerial hyphae which differentiate into bead-like chains of spores. Saccharopolysporae are also characterized by the presence of meso-diaminopimelic acid, arabinose and galactose in their wall peptidoglycan [wall chemotype IV sensu Lechevalier and Lechevalier (21)], have major amounts of phosphatidylglycerol, phosphatidylcholine, phosphatidylethanolamine and phosphatidylmethylethanolamine [phospholipid pattern III sensu Lechevalier et al. (23)], are rich in iso- and anteiso- branched-chain fatty acids $(5,6,10)$, have predominant amounts of tetra-hydrogenated menaquinones with nine isoprene units $(5$, $10)$, but lack mycolic acids $(5,10)$. The DNA base composition of members of the genus falls within the range $66-77 \mathrm{~mol} \% \mathrm{G}+\mathrm{C}(10)$.

The genus Saccharopolyspora contains seven validly described species, Saccharopolyspora erythraea Labeda (19), Saccharopolyspora gregorii Goodfellow et al. (10), Saccharopolyspora hordei Goodfellow et al.

The GenBank/EMBL accession numbers for the nucleotide sequences described in this paper are 709571 (strain AS4.198), AF002818 (S. spinosa) and AF002819 (S. taberi).
(10), Saccharopolyspora rectivirgula Korn-Wendisch et al. (18), Saccharopolyspora spinosa Mertz and Yao (26), Saccharopolyspora taberi Korn-Wendisch et al. (18), and Saccharopolyspora hirsuta Lacey and Goodfellow (20), the type species. These taxa form a distinct phyletic branch within the evolutionary radiation encompassed by the family Pseudonocardiaceae $(7,33)$. Members of the genus Saccharopolyspora are a potentially rich source of natural products but only erythromycin, produced by Saccharopolyspora erythraea, is currently commercially important (4).

An actinomycete, strain AS4.198 ${ }^{\mathrm{T}}$, isolated during an ecological survey of soil actinomycetes in China, was found to have morphological properties consistent with its assignment to the genus Saccharopolyspora. In the present investigation, this organism was examined for an array of genotypic and phenotypic properties and was shown to form a new centre of taxonomic variation within the genus Saccharopolyspora. The name Saccharopolyspora spinosporotrichia is proposed for this organism.

\section{METHODS}

Organisms and culture conditions. Strain AS4.198 ${ }^{\mathrm{T}}$, which was donated by the Institute of Antibiotics of the Chinese Academy of Medical Sciences, was isolated from soil in Jiangxi province, China. The organism was maintained on glucose yeast extract agar (GYEA) (12) at room temperature and as glycerol suspensions $(20 \%, \mathrm{v} / \mathrm{v})$ at $-20^{\circ} \mathrm{C}$. Biomass for the chemotaxonomic studies was prepared by growing the strains in shake flasks of nutrient broth (Oxoid) at $28^{\circ} \mathrm{C}$ 


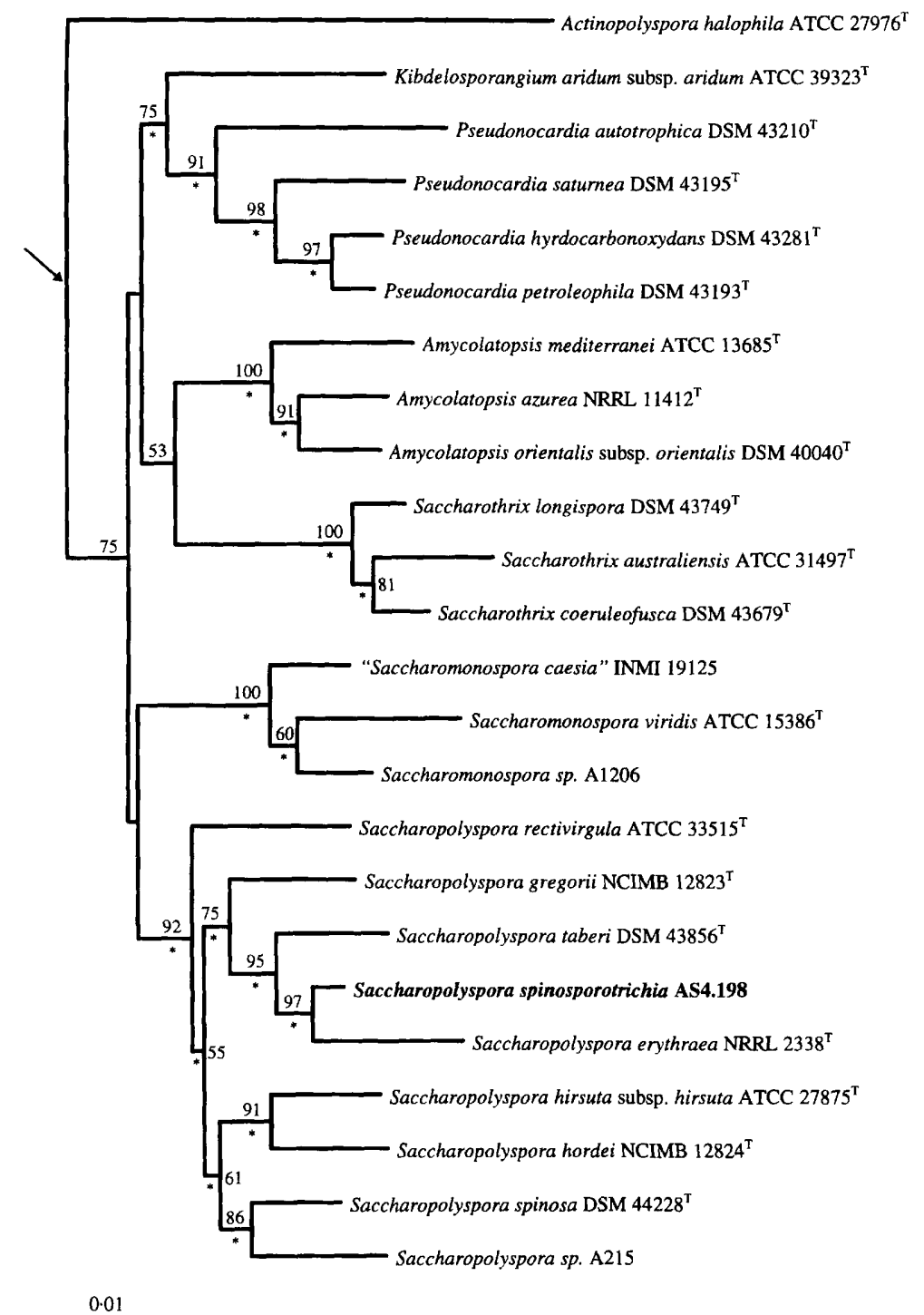

Fig. 1. Neighbour-joining tree (15) based on nearly complete $16 \mathrm{~S}$ rRNA gene sequences showing relationships between Saccharopolyspora spinosporotrichia AS4.198 ${ }^{\top}$ and representative strains of the family Pseudonocardiaceae and related taxa. Asterisks indicate branches that were recovered using the Fitch-Margoliash method. The numbers at the nodes indicate the levels of bootstrap support based on a neighbour-joining analysis of 1000 resampled data sets; only values greater than $50 \%$ are given. The scale bar indicates 0.01 substitutions per nucleotide position. The arrow indicates the estimated position of the root organisms. for $5 \mathrm{~d}$. At maximum growth, the broth cultures were checked for purity, killed with formaldehyde $(1 \%, v / v)$, harvested by centrifugation, washed three times with distilled water and freeze dried. The microbiological tests were incubated at $28{ }^{\circ} \mathrm{C}$ for 2 weeks unless otherwise stated.

Cultural and morphological properties. The undisturbed arrangement of hyphae, especially aerial hyphae and spore chains, was observed on the seven basal media described by Shirling \& Gottlieb (30) using the coverslip technique (16). Growth on coverslips was fixed in $5 \%$ aqueous tannic acid for 10-15 min, washed in distilled water and stained in aqueous crystal violet $(0.2 \%, \mathrm{w} / \mathrm{v})$ for $3 \mathrm{~min}$ then examined at high magnification using a light microscope (Carl Zeiss Universal Microscope). Additional morphological data were obtained by examining dehydrated specimens of the organism, coated with gold, using a Hitachi S-570 scanning electron microscope.

Biochemical and physiological properties. The degradation of casein, gelatin, starch and tyrosine, and the reduction of nitrate were determined using established procedures (11, 13). The production of hydrogen sulphide from peptone iron agar was detected using lead acetate strips and the ability to grow at various salt concentrations $(1-5 \%, w / v)$ on oatmeal agar. The organism was also tested for its ability to grow on a range of sole carbon sources using the basal medium of Stevenson (31) and at $10,25,30,37,45$ and $50^{\circ} \mathrm{C}$ on oatmeal agar. The ability to degrade cellulose was detected using filter-paper strips immersed in a minimal broth $\left(\mathrm{MgSO}_{4}\right.$, $0.5 \mathrm{~g} ; \mathrm{NaCl}, 0.5 \mathrm{~g} ; \mathrm{K}_{2} \mathrm{HPO}_{4}, 0.5 \mathrm{~g} ; \mathrm{KNO}_{3}, 1.0 \mathrm{~g}$; distilled water, 11 ), and incubated at $28^{\circ} \mathrm{C}$ for $30 \mathrm{~d}$. The organism was examined for its ability to coagulate and peptonize defatted milk after incubation at $28^{\circ} \mathrm{C}$ for up to $30 \mathrm{~d}$; the milk was defatted by adding $0.02 \%(\mathrm{w} / \mathrm{v}) \mathrm{CaCO}_{3}$ and centrifuging at 4000 r.p.m. for $30 \mathrm{~min}$.

Chemotaxonomy. Diagnostic isomers of diaminopimelic acid, sugars and polar lipids were detected using established procedures (22). Isoprenoid quinones were extracted and purified according to Collins (3) and analysed by using HPLC (34). The presence of mycolic acids was tested using the acid methanolysis procedure described by Minnikin $e t$ al. (27).

DNA base composition. The $\mathrm{G}+\mathrm{C}$ content of the DNA of the test strain was determined using the thermal de- 
naturation method of Marmur \& Doty (25) with Escherichia coli AS1.365 as the control.

DNA extraction. Biomass was prepared by centrifuging 7-dold cultures of the test strain, $S$. spinosa DSM $44228^{\mathrm{T}}$ and $S$. taberi DSM $43856^{\mathrm{T}}$ grown in shake flasks of tryptic soy broth (Difco) at $30^{\circ} \mathrm{C}$. Genomic DNA was isolated from the test strains by using a procedure (2) slightly modified from that of Pitcher et al. (28).

Sequencing of 165 rDNA. PCR amplification of $16 \mathrm{~S}$ rDNA was performed as described by Kim et al. (17). The PCR products were purified using 2-Spin Plus Centrifugal Filters (Gelman Sciences) according to the procedure provided by the manufacturer. The purified products were directly sequenced by using a Taq DyeDeoxy Terminator Cycle Sequencing kit (Applied Biosystems) and previously described oligonucleotide primers (2). Sequence gel electrophoresis was carried out and nucleotide sequences were automatically obtained by using an Applied Biosystems DNA sequencer (model 373A) and software provided by the manufacturer.

Analysis of sequence data. The $16 \mathrm{~S}$ rDNA sequences were aligned manually with sequences of Saccharopolyspora and related strains obtained from Ribosomal Database Project (24), EMBL (14) and GenBank databases by using the AL16S program (1). Evolutionary trees were inferred by using the neighbour-joining (29) and least squares (9) treemaking algorithms. Evolutionary distance matrices for these methods were generated as described by Jukes \& Cantor (15). The PHYLIP package (8) was used for making the trees. The resulting unrooted tree topologies were evaluated by carrying out bootstrap analyses of the neighbour-joining data based on 1000 resamplings using the SEQBOOT and CONSENSE programs from the PHYLIP package (8). The root position of the unrooted tree based on the neighbour-joining method was estimated by using Bacillus subtilis (GenBank accession no. K00637) and Bifidobacterium bifidum (M38018) as the outgroup organisms, as described by Swofford \& Olsen (32).

Nucleotide sequence accession numbers. The $16 \mathrm{~S}$ rRNA gene sequences of the test strains have the following EMBL/GenBank accession numbers: strain AS4.198 (Y09571), Saccharopolyspora spinosa (AF002818) and Saccharopolyspora taberi (AF002819). The accession numbers of the reference strains are as follows: Actinopolyspora halophila (X54287), Amycolatopsis azurea (X53199), Amycolatopsis mediterranei (X76957), Amycolatopsis orientalis subsp. orientalis (X76958), Kibdelosporangium aridum subsp. aridum (X53191), Pseudonocardia autotrophica (X54288), Pseudonocardia hydrocarbonoxydans (X76955), Pseudonocardia petroleophila (X55608), Pseudonocardia saturnea (X76956), 'Saccharomonospora caesia' (X76960), Saccharomonospora viridis (X54286), Saccharomonospora sp. (X76961), Saccharopolyspora erythraea (X53198), Saccharopolyspora gregorii (X76962), Saccharopolyspora hirsuta subsp. hirsuta (X53196), Saccharopolyspora hordei (X53197), Saccharopolyspora rectivirgula (X53194), Saccharopolyspora sp. A215 (X76967), Saccharothrix australiensis (X53193), Saccharothrix coeruleofusca (X76963), Saccharothrix longispora (X76964).

\section{RESULTS AND DISCUSSION}

Almost complete 16S rDNA sequences (1269 nucleotides) were obtained for the three test strains. Comparison of these nucleotide sequences with those of

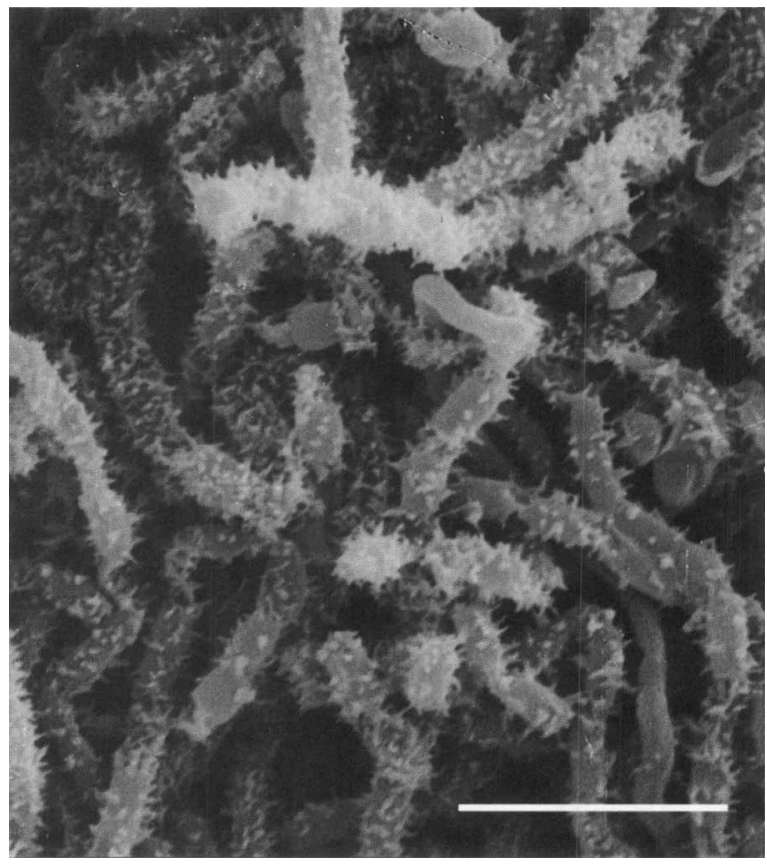

Fig. 2. Scanning electron micrograph showing spinous sporotrichites of Saccharopolyspora spinosporotrichia strain AS4.198 ${ }^{\top}$. Bar, $3.8 \mu \mathrm{m}$

representative strains of the family Pseudonocardiaceae shows that the strain AS4.198 ${ }^{\mathrm{T}}$ belongs to the genus Saccharopolyspora (Fig. 1). The nucleotide sequence of this strain shows substantial differences from the corresponding sequences of its nearest neighbours, namely $S$. erythraea $(97.3 \%$ similarity), $S$. hirsuta $(95.7 \%)$ and S. hordei $(95.4 \%)$. It also shows 34 nucleotide differences with the $16 \mathrm{~S}$ rRNA sequence of S. erythraea.

The assignment of the test strain to the genus Saccharopolyspora Lacey and Goodfellow (20) is also supported by the chemosystematic data. The organism contains meso-diaminopimelic acid as the wall diamino acid; arabinose and galactose as major wall sugars; has a phospholipid pattern containing phosphatidylcholine, and tetra-hydrogenated menaquinones with nine isoprene units as the predominant isoprenoid quinone, but it does not contain mycolic acids. This chemical profile serves to distinguish strain AS4.198 ${ }^{\mathrm{T}}$ from members of all other wall chemotype IV taxa, apart from those classified in the genus Saccharopolyspora $(6,10,20,23)$.

The phenotypic properties of strain AS4.198 ${ }^{T}$ also fit with those expected of Saccharopolyspora strains. The organism is aerobic, non-motile, Gram-positive, nonacid-alcohol-fast and produces an extensively branched substrate mycelium which fragments into rod-shaped elements, and aerial hyphae which carry long chains of spores in a spiral arrangement. The surfaces of the spores are warty (Fig. 2). The organism can be distinguished from members of validly de- 
Table 1. Comparison of properties of Saccharopolyspora spinosporotrichia and other validly described species in the genus Saccharopolyspora

Data for organisms other than S. spinosporotrichia are taken from Lacey \& Goodfellow (20), Goodfellow et al. (10), Labeda (19),

Korn-Wendisch et al. (18) and Mertz \& Yao (26). Abbreviations: Bf, buff; Br, brown; C, colourless; G, grey; O, orange; P, pink; $\mathrm{R}$, red; W, white; Y, yellow; +, positive; -, negative; ND, not determined.

\begin{tabular}{|c|c|c|c|c|c|c|c|}
\hline Characteristic & S. spinosporotrichia & S. erythraea & S. gregorii & S. hirsuta & S. hordei & S. rectivirgula & S. spinosa \\
\hline Spore arrangement & Spirals & Open spirals & $\begin{array}{r}\text { Hooks or } \\
\text { flexuous }\end{array}$ & $\begin{array}{l}\text { Straight to } \\
\text { loose } \\
\text { spirals }\end{array}$ & $\begin{array}{l}\text { Hooks and } \\
\text { spirals }\end{array}$ & Straight & $\begin{array}{l}\text { Hooks and } \\
\text { open loops }\end{array}$ \\
\hline $\begin{array}{l}\text { Colour of aerial } \\
\text { mycelia }\end{array}$ & W-G & P-BrG-W & $\mathrm{W}-\mathrm{Y}$ & $\mathrm{W}$ & $W-Y$ & $\mathrm{~W}$-light $\mathrm{P}$ & W-P \\
\hline Substrate mycelia & Fragments & Branched & Fragments & Fragments & Fragments & Branched & $\begin{array}{l}\text { Fragments } \\
\text { in lipid } \\
\text { media }\end{array}$ \\
\hline $\begin{array}{l}\text { Spores on substrate } \\
\text { mycelia }\end{array}$ & - & - & - & - & - & + & - \\
\hline $\begin{array}{l}\text { Colour of substrate } \\
\text { mycelia }\end{array}$ & $\mathrm{Br}-\mathrm{R}$ & $\mathrm{OY}-\mathrm{RBr}$ & $\mathrm{C}-\mathrm{Bf}$ & $\mathrm{C}-\mathrm{Bf}$ & $\mathrm{C}-\mathrm{Bf}$ & $\mathrm{Y}-\mathrm{O}$ & $\mathrm{G}-\mathrm{OY}-\mathrm{Br}$ \\
\hline $\begin{array}{l}\text { Colour of soluble } \\
\text { pigment }\end{array}$ & $\mathrm{Br}$ & $\mathrm{Y}-\mathrm{POBr}$ & $\mathrm{C}$ & $\mathrm{R}-\mathrm{O}-\mathrm{Y}$ & $\mathrm{C}$ & $\mathrm{ND}$ & $\mathrm{C}-\mathrm{Br}$ \\
\hline Spore ornamentation & Spiny & Spiny & Smooth & Hairy & Smooth & $\begin{array}{l}\text { Smooth or } \\
\text { irregularly } \\
\text { rough }\end{array}$ & Spiny \\
\hline $\begin{array}{l}\text { Degradation of } \\
\text { tyrosine }\end{array}$ & - & + & - & + & + & + & - \\
\hline Hydrolysis of starch & - & + & - & + & + & - & - \\
\hline Reduction of nitrate & - & + & - & - & - & ND & + \\
\hline $\begin{array}{l}\mathrm{NaCl} \text { tolerance } \\
(\%, w / v)\end{array}$ & $2-3$ & $<5$ & $<13$ & $<7$ & $<13$ & $<10$ & $<11$ \\
\hline $\begin{array}{l}\text { Temperature range } \\
\left({ }^{\circ} \mathrm{C}\right)\end{array}$ & $28-37$ & $20-42$ & $10-35$ & $25-50$ & $20-60$ & $37-63$ & $15-37$ \\
\hline \multicolumn{8}{|l|}{$\begin{array}{l}\text { Utilization of } \\
\text { carbohydrates as } \\
\text { sole carbon source }\end{array}$} \\
\hline L-Arabinose & - & + & + & - & + & - & + \\
\hline D-Fructose & + & + & + & + & + & + & + \\
\hline D-Galactose & + & + & + & + & + & ND & - \\
\hline Glycerol & + & + & + & + & + & ND & ND \\
\hline D-Lactose & - & - & - & + & + & + & - \\
\hline D-Maltose & + & + & + & + & + & ND & - \\
\hline D-Mannitol & + & + & + & + & + & + & + \\
\hline D-Mannose & + & + & + & + & + & ND & + \\
\hline D-Raffinose & + & + & ND & + & ND & + & - \\
\hline L-Rhamnose & + & + & + & + & + & + & - \\
\hline Sucrose & + & + & + & + & + & + & - \\
\hline D-Xylose & + & + & + & + & + & + & - \\
\hline
\end{tabular}

scribed Saccharopolyspora species using a battery of phenotypic properties (Table 1).

It is evident from the chemical, molecular systematic and phenotypic data that strain AS4.198 ${ }^{\mathrm{T}}$ should be given species status in the genus Saccharopolyspora. It is, therefore, proposed that the organism be classified in the genus Saccharopolyspora as Saccharopolyspora spinosporotrichia sp. nov.

\section{Description of Saccharopolyspora spinosporotrichia sp. nov. Zhou, Liu, Qian, Kim and Goodfellow}

Saccharopolyspora spinosporotrichia (spi.no.spo.ro.tri. chi.a. L. adj. spinosus thorny; M.L. n. spora a spore; M.L. n. trichia trichite; spinosporotrichia spores bearing needle-like spines).

Aerobic, Gram-positive, non-acid-alcohol-fast actinomycete which forms an extensively branched, reddish- 
brown substrate mycelium which fragments into rodshaped elements; abundant white to grey aerial hyphae are produced. Long spiral spore chains are borne on the aerial mycelium. The spores are spherical with warty surfaces. Good growth occurs on Bennett's, Czapek, Gause's synthetic, inorganic salts-starch, oatmeal and sucrose yeast extract agars. Aerial mycelium production is poor on yeast-maltose extract agar. A brown diffusible pigment is formed on many standard media. Casein and gelatin are degraded but not cellulose, starch or tyrosine. Milk is coagulated and peptonized. $\mathrm{H}_{2} \mathrm{~S}$ is not produced nor is nitrate reduced. The organism can use D-fructose, D-galactose, Dglucose, glycerol, meso-inositol, D-maltose, D-mannitol, D-mannose, D-melibiose, D-ribose, D-sorbitol, Dsucrose and D-xylose as sole carbon sources for energy and growth, but not L-arabinose, D-lactose and Dsorbose. Grows between 25 and $37^{\circ} \mathrm{C}$ and in the presence of $2-3 \%(\mathrm{w} / \mathrm{v})$ sodium chloride. The $\mathrm{G}+\mathrm{C}$ content of the DNA is $70.4 \mathrm{~mol} \%$. The remaining chemical properties of the strain were given earlier. The organism was isolated from soil. The type strain is Saccharopolyspora spinosporotrichia AS4.198 (Chinese Culture Collection of Microorganisms).

\section{ACKNOWLEDGEMENTS}

The authors are grateful to the Institute of Antibiotics, Chinese Academy of Medical Sciences, for the gift of the strain. This work was supported through the Royal SocietyChinese Academy of Sciences Exchange Scheme.

\section{REFERENCES}

1. Chun, J. (1995). Computer-assisted classification and identification of actinomycetes. PhD thesis, University of Newcastle upon Tyne.

2. Chun, J. \& Goodfellow, M. (1995). A phylogenetic analysis of the genus Nocardia with 16S rRNA gene sequences. Int $J$ Syst Bacteriol 45, 240-245.

3. Collins, M. D. (1985). Isoprenoid quinone analyses in classification and identification. In Chemical Methods in Bacterial Systematics, pp. 267-287. Edited by M. Goodfellow \& D. E. Minnikin. London: Academic Press.

4. Embley, T. M. (1992). The family Pseudonocardiaceae. In The Prokaryotes, vol. 1, pp. 996-1027. Edited by A. Balows, H. G. Trüper, M. Dworkin, W. Harder \& K.-H. Schleifer. Berlin: Springer.

5. Embley, T. M., Wait, R., Dobson, G. \& Goodfellow, M. (1987). Fatty acid composition in the classification of Saccharopolyspora hirsuta. FEMS Microbiol Lett 41, 131-135.

6. Embley, T. M., Rostron, J., O’Donnell, A. G. \& Goodfellow, M. (1988). Chemotaxonomy of wall IV actinomycetes lacking mycolic acids. J Gen Microbiol 134, 953-960.

7. Embley, T. M., Smida, J. \& Stackebrandt, E. (1988). Reverse transcriptase sequencing of $16 \mathrm{~S}$ ribosomal RNA from Faenia rectivirgula, Pseudonocardia thermophila and Saccharopolyspora hirsuta, three wall type IV actinomycetes which lack mycolic acids. J Gen Microbiol 134, 961-966.

8. Felsenstein, J. (1993). PHYLIP (phylogeny inference package) version 3.5c. Department of Genetics, University of Washington, Seattle.

9. Fitch, W. M. \& Margoliash, E. (1967). Construction of phylogenetic trees: a method based on mutation distances as estimated from cytochrome $c$ sequences is of general applicability. Science 155, 279-284.

10. Goodfellow, M., Lacey, J., Athalye, M., Embley, T. M. \& Bowen, T. (1989). Saccharopolyspora gregorii and Saccharopolyspora hordei: two new actinomycete species from fodder. J Gen Microbiol 135, 2125-2139.

11. Gordon, R. E. (1967). The taxonomy of soil bacteria. In The Ecology of Soil Bacteria, pp. 293-321. Edited by T. R. G. Gray \& D. Parkinson. Liverpool: Liverpool University Press.

12. Gordon, R. E. \& Mihm, J. M. (1962). Identification of $\mathrm{No}$ cardia caviae nov. comb. Ann NY Acad Sci 98, 628-636.

13. Gordon, R. E., Barnett, D. A., Handerhan, J. E. \& Pang, C. H.-N. (1974). Nocardia coeliaca, Nocardia autotrophica, and the nocardin strain. Int J Syst Bacteriol 24, 54-63.

14. Higgins, D. G., Fuchs, R., Stoehr, P. J. \& Cameron, G. N. (1992). The EMBL data library. Nucleic Acids Res 20, 2071-2074.

15. Jukes, T. H. \& Cantor, C. R. (1969). Evolution of protein molecules. In Mammalian Protein Metabolism, pp. 21-123. Edited by H. N. Munro. New York: Academic Press.

16. Kawato, M. \& Shinobu, R. (1959). On Streptomyces herbaricolor sp. nov., supplement: a simple technique for microscopical observation. Mem Osaka Unit Lib Arts Educ 8, 114.

17. Kim, D., Chun, J., Sahin, N. \& Goodfellow, M. (1996). Analysis of thermophilic clades within the genus Streptomyces by $16 \mathrm{~S}$ ribosomal DNA sequence comparisons. Int $J$ Syst Bacteriol 46, 581-587.

18. Korn-Wendisch, F., Kempf, A., Grund, E., Kroppenstedt, R. M. \& Kutzner, H. J. (1989). Transfer of Faenia rectivirgula (Kurup and Agre, 1983) to the genus Saccharopolyspora as Saccharopolyspora rectivirgula comb. nov. and emended genus description of Saccharopolyspora. Int J Syst Bacteriol 39, 430-441.

19. Labeda, D. P. (1987). Transfer of the type strain of Streptomyces erythraeus (Waksman, 1923) Waksman and Henrici 1948 to the genus Saccharopolyspora Lacey and Goodfellow 1975 as Saccharopolyspora erythraea sp. nov., and designation of the neotype strain for Streptomyces erythraeus. Int J Syst Bacteriol 37, 19-22.

20. Lacey, J. \& Goodfellow, M. (1975). A novel actinomycete from sugar cane bagasse: Saccharopolyspora hirsuta gen. et sp. nov. J Gen Microbiol 88, 75-85.

21. Lechevalier, M.P. \& Lechevalier, H. A. (1970). A critical evaluation of the genera of aerobic actinomycetes. In The Actinomycetales, pp. 393-405. Edited by H. Prauser. Jena, Germany: Gustav Fischer Verlag.

22. Lechevalier, M. P. \& Lechevalier, H. A. (1980). The chemotaxonomy of actinomycetes. In Actinomycete Taxonomy (Society for Industrial Microbiology Special Publication Number 6), pp. 277-284. Edited by A. Dietz \& D. W. Thayer. Arlington: SIM.

23. Lechevalier, M. P., De Bievre, C. \& Lechevalier, H. A. (1977). Chemotaxonomy of aerobic actinomycetes: phospholipid composition. Biochem Syst Ecol 5, 249-260. 
24. Maidak, B. L., Olsen, G. J., Larsen, N., Overbeek, R., McCaughey, M. J. \& Woese, C. R. (1996). The Ribosomal Database Project (RDP). Nucleic Acids Res 24, 82-85.

25. Marmur, J. \& Doty, P. (1962). Determination of base composition of deoxyribonucleic acid from its denaturation temperature. J Mol Biol 5, 109-118.

26. Mertz, F. P. \& Yao, R. C. (1990). Saccharopolyspora spinosa sp. nov., isolated from soil collected in a sugar mill rum still. Int J Syst Bacteriol 40, 34-39.

27. Minnikin, D. E., Hutchinson, I. G., Caldicott, A. B. \& Goodfellow, M. (1980). Thin-layer chromatography of methanolysates of mycolic acid containing bacteria. $J$ Chromatogr 188, 221-233.

28. Pitcher, D. G., Saunders, N. A. \& Owen, R. J. (1989). Rapid extraction of bacterial genomic DNA with guanidium thiocyanate. Lett Appl Microbiol 8, 151-156.

29. Saitou, N. \& Nei, M. (1987). The neighbor joining method: a new method for constructing phylogenetic trees. Mol Biol Evol 4, 406-425.
30. Shirling, E. B. \& Gottlieb, D. (1966). Methods for characterization of Streptomyces species. Int J Syst Bacteriol 16, 317-327.

31. Stevenson, I. J. (1967). Utilization of aromatic hydrocarbons by Arthrobacter spp. Can J Microbiol 13, 205-211.

32. Swofford, D. L. \& Olsen, G. J. (1990). Phylogenetic reconstruction. In Molecular Systematics, pp. 411-501. Edited by D. Hillis \& C. Moritz. Sunderland, USA: Sinauer Associates.

33. Warwick, S. T., Bowen, T., McVeigh, H. \& Embley, T. M. (1994). A phylogenetic analysis of the family Pseudonocardiaceae and the genera Actinokineospora and Saccharothrix with 16S rRNA sequences and proposal to combine the genera Amycolata and Pseudonocardia in an emended genus Pseudonocardia. Int J Syst Bacteriol 44, 293-299.

34. Wu, C., Lu, X., Qin, M., Wang, Y. \& Ruan, J. (1989). Analysis of menaquinone compound in microbial cells by HPLC. Microbiology (English translation of Mikrobiologiya) 16, 176-178. 